\title{
Effect of different storage conditions on analytical and sensory quality of thermally processed milk based germinated Foxtail millet porridge
}

Article

Accepted Version

Sharma, N., Alam, T., Goyal, S.K., Fatma, S., Pathania, S. and Niranjan, K. (2018) Effect of different storage conditions on analytical and sensory quality of thermally processed milk based germinated Foxtail millet porridge. Journal of Food Science, 83 (12). pp. 3076-3084. ISSN 0022-1147 doi: https://doi.org/10.1111/1750-3841.14371 Available at https://centaur.reading.ac.uk/79840/

It is advisable to refer to the publisher's version if you intend to cite from the work. See Guidance on citing.

To link to this article DOI: http://dx.doi.org/10.1111/1750-3841.14371

Publisher: Wiley

All outputs in CentAUR are protected by Intellectual Property Rights law, including copyright law. Copyright and IPR is retained by the creators or other copyright holders. Terms and conditions for use of this material are defined in the End User Agreement. 


\section{www.reading.ac.uk/centaur}

\section{CentAUR}

Central Archive at the University of Reading

Reading's research outputs online 
4 Niranjan $^{\mathrm{d}}$

5

6

7

\section{Abstract}

\section{processed milk based germinated Foxtail millet porridge}

Nitya Sharma ${ }^{\text {a* }}$, Tanweer Alam ${ }^{\text {b }}$, S.K. Goyal ${ }^{\mathrm{a}}$, Sana Fatma ${ }^{\mathrm{c}}$, Sheetaal Pathania ${ }^{\mathrm{d}}$, Keshavan

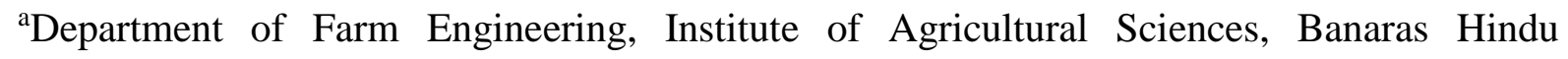
University, Varanasi (India)

${ }^{\mathrm{b}}$ Indian Institute of Packaging, New Delhi (India)

${ }^{\mathrm{c} C e n t r e ~ o f ~ F o o d ~ S c i e n c e ~ a n d ~ T e c h n o l o g y, ~ B a n a r a s ~ H i n d u ~ U n i v e r s i t y, ~ V a r a n a s i ~(I n d i a) ~}$

${ }^{\mathrm{d}}$ Department of Food and Nutritional Sciences, University of Reading, Whiteknights, Reading (United Kingdom)

*Corresponding author email ID: nitya.sharma64@gmail.com

Foxtail millet porridge was prepared using germinated grains and milk and was evaluated for its storage stability after thermal processing at Ultra High Temperatures (UHT) of $142{ }^{\circ} \mathrm{C}$ for $5 \mathrm{~s}$ and Retort processing temperatures of $121.5^{\circ} \mathrm{C}$ for $15 \mathrm{~min}$. Various physical, chemical and microbial changes of the porridge were studied for a storage period of 180 days at $25 \pm 1$ ${ }^{\circ} \mathrm{C}$. Using consumer perception and survival analysis, the predicted shelf life of the UHT treated and retort processed foxtail millet porridge samples stored at $25 \pm 1{ }^{\circ} \mathrm{C}$ was found to be $186 \pm 9$ days and $245 \pm 15$ days, respectively. Also, data from consumer liking, profiling, physical, chemical and microbial parameters showed significant changes $(\mathrm{p}<0.05)$ in the thermally treated packaged porridge samples over time. As the consumer overall acceptability decreased, the detection of positive attributes (Thick and uniformly coloured texture and appearance; grainy mouth texture; caramel taste and aroma) in the porridge decreased, while the detection of negative attributes (Uneven, decoloured, and curdled texture and appearance; 
sticky mouth texture; cooked, sour and off smell; cooked, sour and off taste) increased. The

present study could establish a significant difference $(\mathrm{p}<0.05)$ in the storage induced properties of UHT and retort processed porridge samples. The analytical evaluation of foxtail millet porridge found that UHT treated porridge was better in quality, but consumers preferred retort processed porridge.

Keywords: Foxtail millet porridge, retort processing, UHT, survival analysis, CATA sensory analysis

Practical Application: The quality and sensory attributes, evaluated for UHT treated and retort processed porridge samples during the storage period of 180 days, were found to be contradictory. Based on the results of CATA sensory analysis, the shelf life of UHT treated and retort processed porridge samples was predicted to be more than 6 months. Therefore, both UHT treatment and retort processing can be effectively applied to prepare a ready to eat milk based porridge using germinated foxtail millet grains.

\section{Introduction}

Millet is a commonly consumed crop in the arid and semi-arid tropics. Whole millet grains are used as an ingredient for developing various food products in Asia and Africa. Foxtail millet (Setaria italica L.) is a minor millet which is usually used for feed formulations in many parts of the world. However, its minimum requirement of agricultural inputs, pertinent nutrient composition and health benefitting properties like cancer prevention, hypoglycaemic and hypolipidemic effects, is now making it an important commodity for agricultural scientists to research on, especially to combat food insecurity around the world (Sharma and Niranjan, 2017). As a consequence, developments in agriculture (eg., development of high yielding varieties through breeding programs) and food technology (eg., 
identification of unit operations for processing) are now being employed to improve the quality and palatability of foxtail millet foods and to make them more available in the market for consumption.

Though foxtail millets have been shown to provide nutritional security, but their consumption has been limited due to the presence of some antinutritional effects (Pradeep \& Sreerama, 2015). The literature reports that processing methods like germination can easily supress the antinutritional activities and improve the nutritional and functional properties of these millets (Adebiyi, Obadina, Adebo \& Kayitesi, 2018). Sharma, Saxena and Riar (2015) showed that germination of foxtail millet seeds considerably improved its composition by increasing the bio-availability of bioactive compounds such as total phenolics, antioxidants, total flavonoids, dietary fiber, proteins, minerals, and decreasing the anti-nutritional factors like phytic acid and tannin content.

Thermal treatment has been most effectively used as a method of preservation to extend the shelf life of various liquid food products. Milk based porridge is a common wholesome breakfast meal consumed in almost all parts of the world. Therefore, efforts are now being put to prepare a ready to eat breakfast cereal, that requires minimal or no cooking with maximum retention of nutrients. Apart from this, ready to eat milk based porridges can also be used as a part of mid day meal programmes for school children in under-developed and developing nations, thus adding micronutrients to their daily diet. UHT treatment is a most common practice to improve microbial stability and extend shelf-life of liquid food products, thus maintaining their consistency throughout its shelf life (Mäkinen et al., 2015). Although, many studies have widely used retort processing to prepare various ready to eat milk products (Gautam, Jha, Jafri \& Kumar, 2014; Jha, Patel, Gopal \& Ravishankar, 2011, 2012), but very limited or no study has reported the significance of UHT treatment for large 
scale preparation shelf stable ready to eat milk based porridges (Kumar, Harish, Subramanian, Kumar \& Nadanasabapathi, 2017). Therefore, a study was conducted to prepare a milk based porridge, using germinated foxtail millet grain flour. This porridge was evaluated for its stability after UHT treatment and retort processing to decide the extent of thermal treatment required to prepare a ready to eat porridge. Finally, various quality attributes such as physical, chemical, microbial and sensory parameters were studied for the foxtail millet porridge during a storage period of 180 days at $25 \pm 1{ }^{\circ} \mathrm{C}$ to investigate the effect of thermal treatment on storage stability.

\section{Materials and Methods}

\section{Formulation of Foxtail millet porridge}

Foxtail millet (Setaria italica L.) grains obtained from authorized grain centres of Varanasi (India), was subjected to germination using method as described by Sharma, Goyal, Alam, Fatma and Niranjan (2018). These germinated grains were then dried to a final moisture content of 7-8\% and milled into fine flour using a Laboratory miller (PERTEN 3100, Huddinge, Sweden) with particle size ranging between 100-200 $\mu \mathrm{m}$. The foxtail millet flour obtained after germination was cooked in milk (2\% fat; $8.5 \%$ SNF) and mixed with appropriate levels of powdered sugar. Various combinations of foxtail millet flour, milk and powdered sugar, used to prepare porridge were studied for its sensory characteristics based on a 9-point Hedonic scale using semi-trained sensory panel (with prior experience of sensory evaluation of milk based porridge like products) consisting of 10 judges in the age group of $25-45$ years. This sensory evaluation was done at room temperature $\left(25 \pm 2{ }^{\circ} \mathrm{C}\right)$. 
milk and germinated foxtail millet flour, respectively, was considered most suitable for the porridge premix. For preparation of foxtail millet porridge, the milk was heated to $90 \pm 2{ }^{\circ} \mathrm{C}$ in a steam jacketed vessel (5 ltr capacity) and appropriate amounts of powdered sugar and germinated foxtail millet flour was added to it. The temperature of mix was maintained at 90 $\pm 2{ }^{\circ} \mathrm{C}$ for $2 \mathrm{~min}$, with gentle and constant stirring during cooking using a mixture emulsifier for uniform heating and to prevent clump formation. Fresh prepared foxtail millet porridge was then cooled to $25 \pm 2{ }^{\circ} \mathrm{C}$ and then subjected to two different types of thermal treatments: Ultra High Temperatures (UHT) of $142{ }^{\circ} \mathrm{C}$ for $5 \mathrm{~s}$ and Retort processing temperatures of $121.5^{\circ} \mathrm{C}$ for $15 \mathrm{~min}$.

The heat-treated foxtail millet porridge samples were packaged in aluminum based LDPE pouches $(250 \mathrm{ml}$ each), with a thickness of 30 gauge. The porridge samples were then examined and compared for two different heat treatments: UHT treatment and retort processing. The packaged samples were then stored at $25 \pm 1{ }^{\circ} \mathrm{C}$ and studied for its shelf life for a storage period of 180 days.

\section{UHT treatment}

For UHT treatment, the freshly prepared foxtail millet porridge was cooled and treated at ultra-high temperatures of $142{ }^{\circ} \mathrm{C}$ for $5 \mathrm{~s}$ and packaged in sterilized aluminium based LDPE pouches in a sterile UV chamber. This was carried out in a heat exchanger processing unit (Armfield FT74XTS UHT/HTST System, Hampshire, UK) equipped with standard tubular heat exchanger (FT74-20-MKIII, Hampshire, UK) tubes to maintain the processing temperature. The porridge sample was added through the feeding tank and inlet, preheating, processing and cooling temperatures were recorded to be at $42{ }^{\circ} \mathrm{C}, 94{ }^{\circ} \mathrm{C}, 142{ }^{\circ} \mathrm{C}$ and $35^{\circ} \mathrm{C}\left( \pm 2{ }^{\circ} \mathrm{C}\right)$, respectively, and a pressure of $5.7 \pm 2 \mathrm{bar}$. 


\section{Retort processing}

For retort processing, the freshly prepared porridge was first cooled and then packaged in aluminium based LDPE pouches and then subjected to thermal treatment at a

122 temperature of $121.5^{\circ} \mathrm{C}$ for a period of $15 \mathrm{~min}$ in a pilot-scale horizontal stationary retorting system (Lakshmi Engineering, Chennai, India), as optimized by Gautam et al. (2014) for Chhana kheer. The steam-air overpressure was maintained at $20 \pm 2{ }^{\circ} \mathrm{C}$ during the process. In the end of the process, rapid cooling was done by recirculating cool water at $27 \pm 2{ }^{\circ} \mathrm{C}$. A $\mathrm{Cu} / \mathrm{CuNi}$ thermocouple (Lakshmi Engineering, Chennai, India) was inserted in three retort processed pouches containing porridge, in every batch to obtain heat penetration data and record the process lethality values $\left(\mathrm{F}_{\mathrm{o}}\right)$.

\section{Storage-induced changes in the quality of thermally processed foxtail millet porridge}

Both UHT treated and retort processed foxtail millet porridge packaged in aluminium based LDPE pouches were stored at $25 \pm 1{ }^{\circ} \mathrm{C}$ and $55 \pm 5 \%$ relative humidity (of storage room) for 180 days. Random samples were withdrawn at 20 days interval during storage and analysed for changes in various quality attributes.

Viscosity. Steady shear viscosity of packaged foxtail millet porridge samples was performed on Bohlin C-VOR 150 rheometer (Malvern Instruments Ltd., Malvern, Worceshire, UK) using C25 DIN 53019 coaxial cylinder geometry. Sample flow curves were recorded in linear progression with shear rate from 10 to $1000 \mathrm{~s}^{-1}$ for $120 \mathrm{~s}$ with isothermal temperature programming. Flow curves of the samples were obtained by plotting instantaneous viscosity against respective shear rates. Temperature condition was maintained strictly at $25 \pm 1{ }^{\circ} \mathrm{C}$ for measurement since viscosity of a substance changes substantially with temperature. All measurements were conducted in triplicates. Herschel-Bulkley's model 
142 was used to determine consistency $(K)$ coefficient and flow behaviour index $(n)$ of the stored 143 porridge samples by modelling the steady state flow curves (Steffe, 1996).

$144 \sigma=\sigma_{0}+K \dot{\gamma}^{n}$

145 Where, $\sigma_{0}$ is the yield stress and $\dot{\gamma}$ is the shear rate.

146 pH. Orion star A111 benchtop pH meter (EW-58825-04, Illinois, US) was used to 147 determine the $\mathrm{pH}$ of packaged foxtail millet porridge samples. Measurement were taken in 148 triplicates at $25 \pm 1{ }^{\circ} \mathrm{C}$.

149 Whiteness index. Spectrophotometer ColorLite sph850 (ColorLite GmbH, Katlenburg150 Lindau, Germany) was used for colour measurements of packaged porridge samples and 151 results were expressed as $L^{*} a^{*} b^{*}$ coordinates. The CIELAB system consisted of 152 colorimetric indices $\mathrm{L}^{*}$ (lightness) $\mathrm{a}^{*}$ and $\mathrm{b}^{*}$ (green-red and blue-yellow colorations, 153 respectively). Whiteness index of porridge was measured at $25 \pm 1{ }^{\circ} \mathrm{C}$ using following 154 equation (Loypimai and Moongngarm, 2015).

Whiteness Index $=100-\left[\left(100-L^{*}\right)^{2}+\left(a^{*}\right)^{2}+\left(b^{*}\right)^{2}\right]^{0.5}$

Each sample was collected in glass container, measured at 3 different positions and the average of the values were taken. All the measurements were taken while keeping the external light and temperature conditions similar to minimise variation in results. 
Proteolysis, lipolysis, oxidation and Maillard reaction. Free amino groups in packaged

160

161 foxtail millet porridge samples were determined in terms of trinitrobenzene sulfonic acid (TNBS) value by the method modified by Spadaro, Draghetta, Del Lama, Camargo and Greene (1979). Similarly, the free fatty acid (FFA) was estimated using a titration method suggested by Deeth and Fitz-Gerald (1975).

The fat oxidation during storage in the foxtail millet porridge samples was determined in terms of thiobarbituric acid (TBA) value using the method of Sidwell, Salwin and Mitchell (1955). Finally, the Maillard reaction in the porridge samples was determined in terms of hydroxymethylfurfural (HMF) content using the method of Keeney and Bassette (1959).

Microbial changes. The stored samples were analysed for total plate count, yeast and mould count and coliform count using plate count agar (PCA), potato dextrose agar (PDA) and violet red bile agar (VRBA), respectively. The presence or absence Clostridium botulinum, Salmonella $s p$ and Staphylococcus aureus was confirmed using reinforced clostridial agar, bismulth sulphite agar and mannitol salt agar, respectively for standard plate count method. An ethical committee then monitored the microbial changes to ensure its safety to be consumed.

\section{Shelf life evaluation}

Sensory evaluation. To carry out sensory tests, the ethical committee considered the following limit values for acceptable porridge life: $\mathrm{pH}$ between 6.6 to 7.0 and total bacterial count less than 30,000 CFU ml ${ }^{-1}$. Regular porridge consuming individuals ( $\mathrm{n}=100,48$ males and 52 females in age group 25 - 45 years) were recruited and presented with 9 UHT treated and 9 retort processed samples stored for different time periods at $25 \pm 1{ }^{\circ} \mathrm{C}(0,20,40,60$, $80,100,120,140,160$ and 180 days). Total number of samples were randomized and divided 
into two batches for each treatment to avoid fatigue of the panellists. For each treatment, two sensory sessions were carried out in a day and the panellists were required to compare five samples at a time. For example, in the first session samples stored from 0 to 80 days were compared, while in the second session samples stored at 100 to 180 days were compared. Similar methods were applied to prepare porridge samples at different time intervals such that the samples for all the storage times were ready on the day of sensory evaluation. The method of sensory analysis was followed as described by Richards, Buys and De Kock (2016).

The consumer study was carried out using the following procedure:

1) Consumers were asked for their porridge eating patterns and were selected if they consumed any milk/cereal-based porridge at least thrice a week.

2) The individuals were asked if they would normally buy this product from the market and consume it. They were asked to answer in "yes" or "no".

3) The consumers were then asked to rate the samples based on its appearance, consistency, taste, aroma, flavour and overall liking on a 9 point hedonic scale (1 being "dislike extremely" and 9 being "like extremely") and the final overall liking score was used to rate thermally treated porridge samples.

4) Finally, they were asked to give a sensory profile of the samples based on a list of check-all-that-apply (CATA) sensory attributes that could appropriately describe the packaged porridge samples. Following were the 15 quality attributes: Visual texture and appearance- thick, unevenness, uniform colour, discoloration, curdling; In mouth texture- grainy, sticky; Smell: caramel, cooked, sour, off; Taste: caramel, cooked, sour, off. 

hedonic scales and CATA questions. The panellists were explained about the nature of

206

207 experiments without disclosing the identity of samples. They were required to fill up the form while evaluating the sample in isolated environments on separate tables at room temperatures and were not allowed to make any changes thereafter. Filtered water was provided to the consumers to neutralize and clean their palate before and in between sample tasting.

Survival analysis. Survival analysis was used to estimate the shelf life of the UHT treated and retort processed foxtail millet porridge samples using the results obtained from consumers when asked if they would normally consume the foxtail millet porridge stored at $25 \pm 1{ }^{\circ} \mathrm{C}$ for a time period of 180 days (Hough, Langohr, Gómez, \& Curia, 2003; Gambaro, Fiszman, Giménez, Varela \& Salvador, 2004a; Gambaro, Gimenez, Varela, Garitta \& Hough, 2004b; Gambaro, Ares \& Gimenez, 2006). The methodology is primarily focused on the shelf life hazard on the consumer rejecting the product and not on the product deterioration. Discrete statistical distribution (Weibull, logistic, Gaussian, log-logistic and exponential) were fitted to the data obtained in the consumer test and the best fit (obtained by a visual inspection of the curves) was used to express $F(t)$ (Richards et al., 2016).

Finally, the shelf life of the packaged foxtail millet porridge was obtained by substituting the parameters found in the previous fit followed by considering 25 and $50 \%$ consumer rejection (Hough et al., 2003; Gambaro et al., 2006; Gimenez et al., 2007; Cruz et al., 2010).

\section{Statistical analyses}

The score of all the sensory attributes and the results obtained from each set of experiments were analysed statistically using one-way analysis of variance (ANOVA) to find the 
significance of variation in the data obtained and the mean of triplicate experimental values along with their standard deviations were reported. The difference among the experimental treatments was determined using least significant difference (LSD). Minitab 17.0 software was used for the analysis with a statistical significance set at $p<0.05$.

\section{Results and Discussion}

\section{Quality evaluation of UHT treated and retort processed Foxtail millet porridge}

The heat-treated foxtail millet porridge samples were packaged in aluminum based LDPE pouches. The packaged samples were then stored at $25 \pm 1{ }^{\circ} \mathrm{C}$ and studied for its shelf life for a storage period of 180 days. Following quality attributes of the porridge samples were studied during storage.

Viscosity. The foxtail millet porridge samples treated under UHT temperatures and retort processing temperatures adequately fitted the Herschel-Bulkley's model at $25 \pm 1{ }^{\circ} \mathrm{C}$ and were found to exhibit pseudoplastic behavior. The viscosity increased from 3.935 to 4.490 mPa.s and 4.610 to $5.211 \mathrm{mPa}$.s after 180 days of storage at $25 \pm 1{ }^{\circ} \mathrm{C}$ for UHT treated and retort processed samples, respectively (Figure 1-a). The difference in the viscosity values between both samples revealed that UHT treatment of the porridge did not significantly increased the viscosity of the porridge, as compared to retort processing. For, both the treatments (UHT and retort), the samples showed a significant change $(\mathrm{p}<0.05)$ in its viscosity only after 80 days of storage. Since the viscosity values remained below $10 \mathrm{mPa}$.s, so there were no signs of clotting or gelation (Kocak and Zadow, 1985). This age thickening could be due to structural rearrangements caused due to thermal process induced changes in casein micelles, proteins and fat globules. Storage of thermally processed porridge also causes modifications like aggregation, denaturation, polymerization, etc. in the continuous 
phase by increasing the volume of the dispersed components (Ranalli, Andrés \& Califano, 2017). These results were in agreement with the findings of Abdulghani, Prakash, Ali and Deeth (2015) for UHT milk fortified with iron, magnesium and zinc.

In addition to this, as characterized in Table 1 , the yield stress $\left(\sigma_{0}\right)$ increased significantly $(\mathrm{p}<0.05)$ after 80 days and then decreased after 160 days of storage for UHT treated samples, while $\sigma_{0}$ increased significantly $(\mathrm{p}<0.05)$ after 60 days of storage and decreased after 160 days of storage for retort processed samples. Consistency coefficient $(K)$ significantly $(\mathrm{p}<0.05)$ increased between 80 to 140 days of storage. However, the flow consistency index $(n)$ remained unaffected throughout the storage period. This behavior of the Herschel-Bulkley's equation parameters, were also studied by Ranalli et al. (2017), who quoted similar results for a milk product, Dulce de leche-like product enriched with emulsified pecan oil. Higher values of $\sigma_{0}$ and $K$ for retort processed foxtail millet porridge samples as compared to the UHT treated foxtail millet porridge samples could be due to intense thermal treatment of the porridge in case of retort processing. Fermented finger millet thin porridge was also found to have higher values of $\sigma_{0}$ and $K$ with the increase in the intensity of the thermal treatment (Ojijo \& Shimoni, 2004). These changes in the rheology of porridge has been explained by Datta and Deeth (2001) in terms of weakening of milk protein structure because of the proteolytic breakdown by microorganisms.

pH. The $\mathrm{pH}$ of the porridge samples dropped from an initial average value of 7.00 to 6.64 and 6.78 to 6.60 after a storage period of 180 days at $25 \pm 1{ }^{\circ} \mathrm{C}$ for UHT treated and retort processed samples, respectively (Figure 1-b). Similar type of reduction in $\mathrm{pH}$ values for milk with storage was explained by Gaucher, Mollé, Gagnaire and Gaucheron (2008), stating precipitation of calcium phosphate, dephosphorylation of casein, breakdown of lactose, or proteolysis, as one of reasons. The difference in the values of $\mathrm{pH}$ for UHT treated and retort 
processed samples could be due to the use of different temperatures for the treatment of porridge samples. The fact that higher processing temperatures can lead to a higher $\mathrm{pH}$ was also established by Zamberlin and Samaržija (2017) for different heat treatments given to sheep's milk.

Whiteness index. The whiteness index of UHT treated porridge varied significantly $(\mathrm{p}<$ 0.05) with the retort processed porridge, whereas, only a slight decrease in the whiteness index was observed in its values during the storage period of 180 days at $25 \pm 1{ }^{\circ} \mathrm{C}$ (Figure 1 c). A whiteness index value of 59.39 (a.u.) was calculated for UHT treated porridge and 56.64 (a.u.) for retort processed porridge, which was found to decrease to 55.60 (a.u.) and 48.63 (a.u.), respectively, with storage at $25 \pm 1^{\circ} \mathrm{C}$ for 180 days. This clearly stated that high temperature treatment for longer time periods caused browning of the foxtail millet porridge as compared to the high temperature treatment for shorter time periods, which was in agreement with the studies done by Srikaeo, Furst, Hosken and Ashton (2005). Slight change in the colour of semi-skimmed UHT milk with storage was also observed by Gaucher et al. (2008).

Cooking of grains causes gelatinisation of starch present in them, thus imparted higher $\mathrm{a}^{*}$ (redness) and $\mathrm{b}^{*}$ (yellowness) values to high temperature treated porridge (data not shown). Another factor that could have affected the whiteness index of the porridge is the Maillard reaction taking place in the milk during heating. Intensive heat treatment for longer times causes formation of brown pigments called melanoidins from reducing sugars and proteins present in the milk (Van Boekel, 1998). Apart from this, proteolysis of the milk product during storage could also be a reason that affects the whiteness of milk as it results in the formation of aggregates that causes browning (Jensen et al., 2015). 
Chemical reactions. Most of the microorganisms get inactivated by thermal treatment, but still there are some heat-resistant enzymes of native and bacterial origin that survive high temperatures and causes flavour and textural defects in milk and milk based porridges (Datta, Elliott, Perkins \& Deeth, 2002). Proteolysis of high temperature treated milk and milk products during storage at room temperature is one of the major factors limiting its shelf life due to the changes in texture and flavor (Datta et al., 2002). Proteolysis causes formation of off-flavours in milk due to the release of tyrosine and the textural changes are due to age gelation due to formation of complexes on hydrolysation of caseins (Richards et al., 2016). The level of proteolysis, measured in terms of TNBS value, of packaged foxtail millet porridge samples at $25 \pm 1{ }^{\circ} \mathrm{C}$ increased at a slow rate for upto a storage period of 80 days for UHT treated porridge and 60 days for retort processed porridge and soon after this, it increased at a higher rate (Figure 2-a). The TNBS values increased from 0.847 to $2.880 \mu \mathrm{mol}$ $\mathrm{ml}^{-1}$ and 0.885 to $2.962 \mu \mathrm{mol} \mathrm{ml} \mathrm{ml}^{-1}$ for UHT treated and retort processed samples, respectively. No significant change was observed for TNBS values of both thermal treatments. This study complied with the findings of El-Din, Aoki and Kako (1991) and Gaucher et al. (2008), who observed an increase in non-casein nitrogen and non-protein nitrogen in UHT treated milk due to proteolysis caused with storage.

Thiobarbituric acid (TBA) reactive substances is a measure of the formation of secondary oxidation products such as carbonyls. Lipid present in milk may undergo chemical and physical changes such as autoxidation and formation of trans fatty acids during processing and storage which leads to production of low molecular weight compounds (aldehydes, ketones and lactones) with losses in sensory quality (Semma, 2002). High temperatures (above $100{ }^{\circ} \mathrm{C}$ ) treatment of milk or milk based products are found to be rich in polyunsaturated fatty acids, so they contribute to the start of oxidation reactions (Datta et al., 
observed for packaged foxtail millet porridge stored at $25 \pm 1{ }^{\circ} \mathrm{C}$ for 180 days (Figure 2-b). The TBA values increased from 0.045 to 0.098 and 0.066 to 0.113 as absorbance at $532 \mathrm{~nm}$ for UHT treated and retort processed porridge samples, respectively. Similar observation were made by Gautam et al. (2014) for chhana kheer and Ranalli et al. (2017) for Dulce de leche-like product enriched with emulsified pecan oil.

HMF is formed as a result of progression of Maillard reactions and it increased with the increase in the storage time (Jha et al., 2012). If the heat treatment is applied to milk and milk products, HMF is formed due to isomerisation and subsequent degradation of sugars (Morales \& Jiménez-Pérez, 1998; Bunkar, Jha, Mahajan \& Unnikrishnan, 2014). The HMF content increased from 18.34 to $59.44 \mu \mathrm{mol} \mathrm{ml}^{-1}$ and 25.82 to $66.38 \mu \mathrm{mol} \mathrm{ml}{ }^{-1}$ at $25 \pm 1{ }^{\circ} \mathrm{C}$ during a storage period of 180 days for UHT treated and retort processed porridge samples, respectively (Figure 2-c). Higher HMF values in retort packaged samples could be due to application of high temperatures for longer times.

Free fatty acid is an indicator of oxidative degradation of lipids present in the milk products. During storage, lipid in food products is readily hydrolyzed by enzymes such as lipases (Clayton \& Morrison, 1972). However, lipases are denatured during thermal processing, therefore, it is hypothesized that the increase in FFA content in stored products could be a result of decomposition of hydroperoxide (Thakur and Arya, 1990; Khan, Semwal, Sharma \& Bawa, 2014). Figure 2-d depicts an increase in the FFA content from 2.34 to 3.21

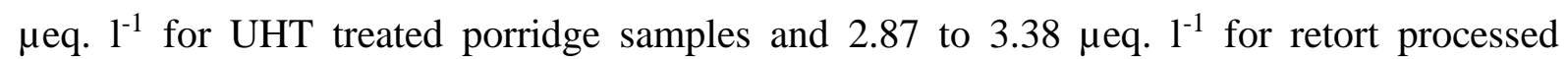
porridge samples during storage upto 180 days, thus evaluating the extent of lipolysis in foxtail millet porridge samples. Gautam et al. (2014) explained the increase in lipolysis during storage of chhana kheer due to the release of free fatty acids during heat treatment and the presence of high moisture content. While the increase in maillard browning was attributed 
to the conversion of sulfhydryl (-SH) groups to disulphide (S-S) groups in the presence of oxygen. Difference in the values of FFA for both the thermal treatments was also observed, which could be attributed to the high temperature treatment for longer times in retort processing and shorter times in UHT treatment.

Microbial changes. The packaged foxtail millet porridge samples stored at $25 \pm 1{ }^{\circ} \mathrm{C}$ were subjected to microbial analysis to ensure it is safe to consume for sensory analysis. Table 2 characterizes the data obtained from microbial analysis for UHT treated and retort processed porridge samples for the storage period of 180 days at $25 \pm 1{ }^{\circ} \mathrm{C}$. It was observed that the total plate count and yeasts and molds count for samples packaged after UHT treatment and stored at $25 \pm 1{ }^{\circ} \mathrm{C}$ showed a slightly higher microbial load as compared to the retort processed samples stored at $25 \pm 1{ }^{\circ} \mathrm{C}$ for the total storage period of 180 days. This could be either due to the different time-temperature combinations for both heat treatments, or due to ineffective handling of the product while packaging. However, no significant difference was observed in the microbial quality. No coliforms and organisms such as Clostridium botulinum, Salmonella spp. and Staphylococcus aureus were detected in the samples. In view of the $\mathrm{pH}$ and microbiological results, the ethical committee decided that all the samples were adequate for sensory tests by humans.

\section{Consumer perception and shelf life modelling} statistical analysis, it was found that the overall liking scores from the consumers significantly decreased with the progression of the storage period at $25 \pm 1{ }^{\circ} \mathrm{C}(\mathrm{p}<0.05)$. A linear correlation $\left(r^{2}=0.98\right)$ was found between the overall acceptability scores (obtained 368 from the consumers' panel) and the storage time. Hough et al. (2002) suggested determination of shelf life with identifying the first significant $(\mathrm{p}<0.05)$ negative change in 
the overall acceptability of the product. As can be seen from Figure 3-a, the overall acceptability significantly $(\mathrm{p}<0.05)$ changed with progression of the storage period.

Consumers checked all 15 sensory attributes to describe both thermally processed porridge samples as they were presented to them during their storage. The frequency of each sensory attribute in CATA question that has been used to for the porridge samples are presented in Table 3 and 4. Amongst the 15 sensory attributes, 5 positive attributes (Thick and uniformly coloured texture and appearance; grainy mouth texture; caramel taste and aroma) were found to have significantly $(\mathrm{p}<0.05)$ different frequencies for both the porridge samples. This analysis also indicated that the sensory quality of porridge samples deteriorated with time. Similar results were observed by Bruzzone et al. (2015) for milk desserts; Farah, Araujo and Melo (2016) for yoghurts', whey-based beverages' and fermented milks'; Richards et al. (2016) for low-fat UHT milk; Oliveira et al. (2017) for non-fermented probiotic milk and Antúnez, Vidal, Saldamando, Giménez and Ares (2017) for powdered drinks.

Survival analysis. For the consumer sensory data of both UHT treated and retort processed foxtail millet porridge, following standard distribution were compared for loglikelihood: Weibull, logistic, Gaussian, log-logistic and exponential. Table 5 revealed that the log-likelihood values was least for the Weibull distribution, thus showing best fit for the survival analysis of the sensory data. Therefore, the Weibull distribution was selected to model the rejection of packaged foxtail millet porridge samples at $25 \pm 1{ }^{\circ} \mathrm{C}$. Many studies in shelf life determination used Weibull distribution for shelf life modelling of milk products such as probiotic milk (Oliveira et al., 2017); nutricereal based fermented baby food (Rasane, Jha \& Sharma, 2015); yogurt (Karagül-Yuceer, Coggins, Wilson \& White, 1999; Curia, Aguerrido, Langohr \& Hough, 2005; Cruz et al., 2010). 

shelf life, the probability of a consumer rejecting the product i.e., $F(t)$, needs to be selected. Several studies on shelf life predication modelling used $25 \%$ rejection (Gambaro et al. 2004a, 2004b), while some other used $50 \%$ rejection to estimate the shelf life (Gacula \& Singh, 1984; Cardelli \& Labuza, 2001). Thus, over the time both 25 and $50 \%$ rejection were considered in number of studies (Gambaro et al., 2006; Araneda, Hough \& De Penna, 2008; Cruz et al., 2010). Therefore, in the present study, the shelf life of the packaged porridge samples was determined at $50 \%$ consumer rejection.

Amongst both thermal treatments, UHT treated samples were the first to be rejected by the consumers. The first rejection score for UHT treated porridge samples was obtained at 403 day 80 after which the rejection probability accelerated significantly, thus rendering the samples unacceptable by $25 \%$ consumer on day 122 (Figure 3-b), as described by Labuza and Schmidl (1988). While, for retort processed samples, first rejection was obtained at day 140, which accelerated after day 160 (Figure 3-b), with a highest rejection score on day 180 407 resulting in the end of the study. $\pm 1{ }^{\circ} \mathrm{C}$ was found to be 186 days with lower and upper confidence levels of 177 and 195 days. While, for retort processed porridge samples it was found to be 245 days with lower and upper confidence levels of 230 and 260 days. The difference in the shelf life of foxtail millet porridge samples packaged under different thermal treatments could be due to change in product quality due to different heat treatments corresponding to the change in physical and sensory properties of the products such as colour and appearance, flavor and sweetness, body and texture and mouthfeel of the product, which ultimately affected the overall acceptability of the product. The significant $(\mathrm{p}<0.05)$ changes in the sensory perception of the consumers 
417 justified the degradation of the quality of porridge with storage time due to various physico-

418 chemical and microbial changes that occurred after processing (Datta et al., 2002) These

419 results were in agreement with Stoeckel, Lidolt and Hinrichs (2016) and Richards et al. 420 (2016).

\section{Conclusion}

In this study, a premix was developed using germinated foxtail millet flour.

According to the overall acceptability, a ratio of 1:2:1.3 was selected for powdered sugar,

milk and germinated foxtail millet flour, respectively, which was then cooked to prepare a milk based porridge. The main aim of this study was to develop a porridge using this premix and establish a comparison between the storage induced changes in various physical, biochemical, microbial and sensory properties of the porridge, thermally processed using UHT of $142{ }^{\circ} \mathrm{C}$ for $5 \mathrm{~s}$ and Retort processing temperatures of $121.5^{\circ} \mathrm{C}$ for $15 \mathrm{~min}$. The results showed that retort processing at higher temperatures for a longer time was responsible for higher values of $\sigma_{0}$ and $K$; higher values of $\mathrm{pH}$; formation of brown pigments from reducing sugars and proteins present in the milk; and higher values of TNBS, TBA, HMF and FFA. Thus, concluding that the quality of UHT treated porridge samples was better than the retort processed porridge samples during storage. While, in case of shelf life at a storage temperature of $25 \pm 1{ }^{\circ} \mathrm{C}$, the UHT treated samples were the first to be rejected by the consumers, thereby limiting its predicted shelf life to 186 days with lower and upper confidence levels of 177 and 195 days, as compared to the retort processed porridge samples, whose predicted shelf life was found to be 245 days with lower and upper confidence levels of 230 and 260 days. Contrasting results were observed between the UHT and retort processed germinated foxtail millet porridge quality and its consumer acceptance. Though the quality attributes were found to be better for UHT treated porridge samples during the storage 
441 period, but the consumers preferred retort processed porridge samples. Therefore, it was 442 concluded that the extent of thermal treatment needed to prepare a ready to eat porridge, can 443 be decided based on its quality as well as consumer preference.

444 Acknowledgements

Nitya Sharma gratefully acknowledges the support of Commonwealth Scholarship 446 Commission (INCN-2015-124) and Department of Food and Nutritional Sciences, University 447 of Reading. The authors have no conflict of interest.

Author Contributions

Nitya Sharma designed the study, carried out the experiments, interpreted the results

450

451

452

453

454

455

456

457

458

459

460

461

Abdulghani, A. H., Prakash, S., Ali, M. Y., \& Deeth, H. C. (2015). Sensory evaluation and storage stability of UHT milk fortified with iron, magnesium and zinc. Dairy Science \& Technology, 95(1), 33-46.

Adebiyi, J. A., Obadina, A. O., Adebo, O. A., \& Kayitesi, E. (2017). Fermented and malted millet products in Africa: Expedition from traditional/ethnic foods to industrial value-added products. Critical Reviews in Food Science and Nutrition, 1-12. 
Antúnez, L., Vidal, L., de Saldamando, L., Giménez, A., \& Ares, G. (2017). Comparison of consumer-based methodologies for sensory characterization: Case study with four sample sets of powdered drinks. Food Quality and Preference, 56, 149-163.

Araneda, M., Hough, G., \& De Penna, E. W. (2008). Current- status survival analysis methodology applied to estimating sensory shelf life of ready- to- eat lettuce (lactuca sativa). Journal of Sensory Studies, 23(2), 162-170.

Bruzzone, F., Vidal, L., Antúnez, L., Giménez, A., Deliza, R., \& Ares, G. (2015). Comparison of intensity scales and CATA questions in new product development: Sensory characterisation and directions for product reformulation of milk desserts. Food Quality and Preference, 44, 183-193.

Bunkar, D. S., Jha, A., Mahajan, A., \& Unnikrishnan, V. S. (2014). Kinetics of changes in shelf life parameters during storage of pearl millet based kheer mix and development of a shelf life prediction model. Journal of Food Science and Technology, 51(12), $3740-3748$.

Cardelli, C., \& Labuza, T. P. (2001). Application of Weibull hazard analysis to the determination of the shelf life of roasted and ground coffee. LWT-Food Science and Technology, 34(5), 273-278.

Clayton, T. A., \& Morrison, W. R. (1972). Changes in flour lipids during the storage of wheat flour. Journal of the Science of Food and Agriculture, 23(6), 721-736.

Cruz, A. G., Walter, E. H., Cadena, R. S., Faria, J. A., Bolini, H. M., Pinheiro, H. P., \& Sant'Ana, A. S. (2010). Survival analysis methodology to predict the shelf-life of probiotic flavored yogurt. Food Research International, 43(5), 1444-1448. 
Curia, A., Aguerrido, M., Langohr, K., \& Hough, G. (2005). Survival analysis applied to sensory shelf life of yogurts-I: Argentine formulations. Journal of Food Science, 70(7), 442-445.

Datta, N., \& Deeth, H. C. (2001). Age gelation of UHT milk-a review. Food and Bioproducts Processing, 79(4), 197-210.

Datta, N., Elliott, A. J., Perkins, M. L., \& Deeth, H. C. (2002). Ultra-high-temperature (UHT) treatment of milk: comparison of direct and indirect modes of heating. Australian Journal of Dairy Technology, 57(3), 211.

Deeth, H. C., \& Fitz-Gerald, C. H. (1975). A convenient method for determining the extent of lipolysis in milk. Australian Journal of Dairy Technology, 30, 109-111.

El-Din, M. Z., Aoki, T., \& Kako, Y. (1991). Polymerization and degradation of casein in UHT milk during storage. Milchwissenschaft (Germany, FR), 46, 284-287.

Farah, J. S., Araujo, C. B., \& Melo, L. (2017). Analysis of yoghurts', whey-based beverages' and fermented milks' labels and differences on their sensory profiles and acceptance. International Dairy Journal, 68, 17-22.

Gacula Jr, M. C., \& Singh, J., (1984). Statistical methods in food and consumer research. Academic Press, New York.

Gambaro, A., Ares, G., \& Gimenez, A. N. A. (2006). Shelf- life estimation of apple- baby food. Journal of Sensory Studies, 21(1), 101-111.

Gambaro, A., Fiszman, S., Giménez, A., Varela, P., \& Salvador, A. (2004). Consumer acceptability compared with sensory and instrumental measures of white pan bread: 

sensory shelf- life estimation by survival analysis. Journal of Food Science, 69(9), 401-405.

Gambaro, A., Gimenez, A., Varela, P., Garitta, L., \& Hough, G. (2004). Sensory shelf- life estimation of alfajor by survival analysis. Journal of Sensory Studies, 19(6), 500509.

Gaucher, I., Mollé, D., Gagnaire, V., \& Gaucheron, F. (2008). Effects of storage temperature on physico-chemical characteristics of semi-skimmed UHT milk. Food Hydrocolloids, 22(1), 130-143.

Gautam, A. K., Jha, A., Jafri, M., \& Kumar, A. (2014). Optimisation of a process for shelfstable dietetic Chhana kheer and changes in physicochemical properties during storage. International Journal of Dairy Technology, 67(1), 73-81.

Giménez, A., Varela, P., Salvador, A., Ares, G., Fiszman, S., \& Garitta, L. (2007). Shelf life estimation of brown pan bread: A consumer approach. Food Quality and Preference, 18(2), 196-204.

Hough, G., Langohr, K., Gómez, G., \& Curia, A. (2003). Survival analysis applied to sensory shelf life of foods. Journal of Food Science, 68(1), 359-362.

Hough, G., Sánchez, R. H., De Pablo, G. G., Sánchez, R. G., Villaplana, S. C., Gimenez, A. M., \& Gambaro, A. (2002). Consumer acceptability versus trained sensory panel scores of powdered milk shelf-life defects. Journal of Dairy Science, 85(9), 20752080.

Jensen, S., Jansson, T., Eggers, N., Clausen, M. R., Larsen, L. B., Jensen, H. B., Ray, C., Sundgren, A., Andersen, H. J., \& Bertram, H. C. (2015). Storage-induced changes in 
the sensory characteristics and volatiles of conventional and lactose-hydrolyzed UHT processed milk. European Food Research and Technology, 240(6), 1247-1257.

Jha, A., Patel, A. A., Gopal, T. K. S., \& Ravishankar, C. N. (2011). Development of process for long life dairy dessert kheer and its physicochemical properties. International Journal of Dairy Technology, 64, 591-597.

Jha, A., Patel, A. A., Gopal, T. K. S., \& Ravishankar, C. N. (2012). Development of a process for shelf stable dairy dessert dalia and its physico-chemical properties. LWT-Food Science and Technology, 49(1), 80-88.

Karagül-Yüceer, Y., Coggins, P. C., Wilson, J. C., \& White, C. H. (1999). Carbonated yogurt-sensory properties and consumer acceptance. Journal of Dairy Science, 82(7), 1394-1398.

Keeney, M., \& Bassette, R. (1959). Detection of Intermediate Compounds in the Early Stages of Browning Reaction in Milk Products1. Journal of Dairy science, 42(6), 945-960.

Khan, M. A., Semwal, A. D., Sharma, G. K., \& Bawa, A. S. (2014). Studies on the optimization and stability of instant wheat porridge (Dalia) mix. Journal of Food Science and Technology, 51(6), 1154-1160.

Kocak, H. R., \& Zadow, J. G. (1985). Age gelation of UHT whole milk as influenced by storage temperature. Australian Journal of Dairy Technology, 40(1), 14-18.

Kumar, R., Harish, S., Subramanian, V., Kumar, S., \& Nadanasabapathi, S. (2017). Development and quality evaluation of retort processed RTE functional gluten free foxtail millet halwa. Croatian Journal of Food Science and Technology, 9(2), 114121. 
549 Kurniadi, M., Salam, N., Kusumaningrum, A., Nursiwi, A., Angwar, M., Susanto, A.,

550

551

552

553

554

555

556

557

558

559

560

561

562

563

564

565

566

567

568

569 Nurhikmat, A., Triwiyono, \& Frediansyah, A. (2017). Shelf-life prediction of canned "nasi uduk" using accelerated shelf-life test (ASLT)-Arrhenius model. In AIP Conference Proceedings (Vol. 1788, No. 1, p. 030096). AIP Publishing.

Labuza, T. P., \& Schmidl, M. K. (1988). Use of sensory data in the shelf life testing of foods: principles and graphical methods for evaluation. Cereal Foods World, 6(3), 179-200.

Loypimai, P., \& Moongngarm, A. (2015). Utilization of pregelatinized banana flour as a functional ingredient in instant porridge. Journal of Food Science and Technology, 52(1), 311-318.

Mäkinen, O. E., Uniacke-Lowe, T., O’Mahony, J. A., \& Arendt, E. K. (2015). Physicochemical and acid gelation properties of commercial UHT-treated plantbased milk substitutes and lactose free bovine milk. Food Chemistry, 168, 630-638.

Morales, F. J., \& Jiménez-Pérez, S. (1998). Study of hydroxymethylfurfural formation from acid degradation of the Amadori product in milk-resembling systems. Journal of Agricultural and Food Chemistry, 46(10), 3885-3890.

Ojijo, N. K., \& Shimoni, E. (2004). Rheological properties of fermented finger millet (Eleucine coracana) thin porridge. Carbohydrate Polymers, 56(2), 235-242.

Oliveira, D., Vidal, L., Ares, G., Walter, E. H., Rosenthal, A., \& Deliza, R. (2017). Sensory, microbiological and physicochemical screening of probiotic cultures for the development of non-fermented probiotic milk. LWT-Food Science and Technology, 79, 234-241. 
570 Pradeep, P. M., \& Sreerama, Y. N. (2015). Impact of processing on the phenolic profiles of

571

572

573

574

575

576

577

578

579

580

581

582

583

584

585

586

587

588

589

590

591

592 small millets: Evaluation of their antioxidant and enzyme inhibitory properties associated with hyperglycemia. Food Chemistry, 169, 455-463.

Ranalli, N., Andrés, S. C., \& Califano, A. N. (2017). Dulce de leche- like product enriched with emulsified pecan oil: Assessment of physicochemical characteristics, quality attributes, and shelf- life. European Journal of Lipid Science and Technology, 119(7), 1600377.

Rasane, P., Jha, A., \& Sharma, N. (2015). Predictive modelling for shelf life determination of nutricereal based fermented baby food.Journal of Food Science and Technology, 52(8), 5003-5011.

Richards, M., Buys, E. M., \& De Kock, H. L. (2016). Survival analysis, consumer perception and physico-chemical analysis of low fat UHT milk stored for different time periods. International Dairy Journal, 57, 56-61.

Semma, M. (2002). Trans fatty acids: properties, benefits and risks. Journal of Health Science, 48(1), 7-13.

Sharma, S., Saxena, D. C., \& Riar, C. S. (2015). Antioxidant activity, total phenolics, flavonoids and antinutritional characteristics of germinated foxtail millet (Setaria italica). Cogent Food \& Agriculture, 1(1), 1081728.

Sharma, N., \& Niranjan, K. (2017). Foxtail millet: Properties, processing, health benefits, and uses. Food Reviews International, DOI: 10.1080/87559129.2017.1290103, 1-35.

Sharma, N., Goyal, S. K., Alam, T., Fatma, S., \& Niranjan, K. (2018). Effect of Germination on the Functional and Moisture Sorption Properties of High-Pressure-Processed Foxtail Millet Grain Flour. Food and Bioprocess Technology, 11(1), 209-222. 
593

594

595

596

597

598

599

600

601

602

603

604

605

606

607

608

609

610

611

612

613

614

Sidwell, C. G., Salwin, H., \& Mitchell, J. H. (1955). Measurement of oxidation in dried milk products with thiobarbituric acid.Journal of the American Oil Chemists Society, 32(1), 13-16.

Spadaro, A. C. C., Draghetta, W., Del Lama, S. N., Camargo, A. C., \& Greene, L. J. (1979). A convenient manual trinitrobenzenesulfonic acid method for monitoring amino acids and peptides in chromatographic column effluents. Analytical Biochemistry, 96(2), 317-321.

Srikaeo, K., Furst, J. E., Hosken, R. W., \& Ashton, J. F. (2005). Physical properties of cooked wheat grains as affected by cooking temperature and duration. International Journal of Food Properties, 8(3), 469-479.

Steffe, J. F. (1996). Rheological methods in food process engineering. Freeman Press, East Lansing, MI.

Stoeckel, M., Lidolt, M., \& Hinrichs, J. (2017). Modeling Milk Heating Processes for the Production of Milk Shelf- stable without Refrigeration. Chemie Ingenieur Technik, 89(3), 310-319.

Thakur, B. R., \& Arya, S. S. (1990). Packaging requirement and stability of fried wheat snacks (trisnacks). Journal of Food Science and Technology, 27(2), 76-81.

Van Boekel, M. A. J. S. (1998). Effect of heating on Maillard reactions in milk. Food Chemistry, 62(4), 403-414.

Zamberlin, Š., \& Samaržija, D. (2017). The effect of non-standard heat treatment of sheep's milk on physico-chemical properties, sensory characteristics, and the bacterial viability of classical and probiotic yogurt. Food Chemistry, 225, 62-68. 
Table 1 Changes in Hershel-Bulkley parameters of packaged foxtail millet porridge during 626 storage at $25{ }^{\circ} \mathrm{C}$

\begin{tabular}{cccc|ccc}
\hline \multirow{2}{*}{$\begin{array}{c}\text { Storage } \\
\text { time }\end{array}$} & \multicolumn{3}{c|}{ UHT treated samples } & \multicolumn{3}{c}{ Retort processed samples } \\
\cline { 2 - 6 }$($ days $)$ & $\sigma_{0}{ }^{*}$ & $\mathrm{~K}^{*}$ & $\mathrm{n}^{*}$ & $\sigma_{0}{ }^{*}$ & $\mathrm{~K}^{*}$ & $\mathrm{n}^{*}$ \\
& $(\mathrm{~Pa})$ & $\left({\left.\mathrm{Pa} . \mathrm{s}^{\mathrm{n}}\right)}\right.$ & & $(\mathrm{Pa})$ & $\left({\left.\mathrm{Pa} . \mathrm{s}^{\mathrm{n}}\right)}\right.$ \\
\hline 0 & $18.7 \pm 1.5^{\mathrm{aA}}$ & $1.48 \pm 0.07^{\mathrm{a}}$ & 0.55 & $27.5 \pm 1.0^{\mathrm{aB}}$ & $1.63 \pm 0.09^{\mathrm{a}}$ & 0.57 \\
& & & & & \\
20 & $19.4 \pm 1.2^{\mathrm{aA}}$ & $1.52 \pm 0.03^{\mathrm{a}}$ & 0.53 & $28.8 \pm 1.5^{\mathrm{aB}}$ & $1.69 \pm 0.04^{\mathrm{a}}$ & 0.54 \\
40 & $20.1 \pm 1.0^{\mathrm{aA}}$ & $1.57 \pm 0.02^{\mathrm{a}}$ & 0.56 & $29.6 \pm 2.2^{\mathrm{aB}}$ & $1.72 \pm 0.08^{\mathrm{a}}$ & 0.56 \\
60 & $21.5 \pm 1.2^{\mathrm{aA}}$ & $1.60 \pm 0.05^{\mathrm{a}}$ & 0.57 & $33.0 \pm 2.0^{\mathrm{bB}}$ & $1.80 \pm 0.10^{\mathrm{a}}$ & 0.58 \\
& & & & & & \\
& $25.4 \pm 1.5^{\mathrm{bA}}$ & $2.33 \pm 0.10^{\mathrm{b}}$ & 0.54 & $36.8 \pm 1.8^{\mathrm{bB}}$ & $2.50 \pm 0.15^{\mathrm{b}}$ & 0.60
\end{tabular}




\begin{tabular}{llll|lll}
100 & $29.7 \pm 1.8^{\mathrm{bA}}$ & $2.74 \pm 0.07^{\mathrm{b}}$ & 0.52 & $39.9 \pm 2.0^{\mathrm{bB}}$ & $2.97 \pm 0.09^{\mathrm{b}}$ & 0.59 \\
120 & $32.5 \pm 2.0^{\mathrm{bA}}$ & $3.28 \pm 0.11^{\mathrm{b}}$ & 0.56 & $43.5 \pm 1.4^{\mathrm{bB}}$ & $3.48 \pm 0.10^{\mathrm{b}}$ & 0.56 \\
140 & $36.5 \pm 2.0^{\mathrm{bA}}$ & $3.70 \pm 0.10^{\mathrm{b}}$ & 0.58 & $46.0 \pm 1.9^{\mathrm{bB}}$ & $3.86 \pm 0.07^{\mathrm{b}}$ & 0.58 \\
160 & $31.3 \pm 1.5^{\mathrm{cA}}$ & $3.77 \pm 0.08^{\mathrm{c}}$ & 0.53 & $42.6 \pm 1.5^{\mathrm{cB}}$ & $3.92 \pm 0.09^{\mathrm{c}}$ & 0.53 \\
& & & & & \\
180 & $28.8 \pm 1.0^{\mathrm{cA}}$ & $3.89 \pm 0.09^{\mathrm{c}}$ & 0.54 & $38.7 \pm 2.0^{\mathrm{cB}}$ & $4.06 \pm 0.10^{\mathrm{c}}$ & 0.59
\end{tabular}

627 Values are presented as mean \pm standard deviation $(n=3)$

628 Values with different small superscripts in a column differ significantly at $p<0.05$ for each test

629 Values with different capital superscripts in a row differ significantly at $p<0.05$ for each test

630

631

632

633

634

635

Table 2 Microbial analysis of UHT treated and retort processed foxtail millet porridge during 636 the test storage period at $25{ }^{\circ} \mathrm{C}$

\section{Storage period (Days) UHT treated samples \\ Retort processed samples}

\section{Total plate count (log CFU/g of sample)}

0

ND

ND

30

ND

ND

60

ND

ND

90

$2.11 \pm 0.02^{\mathrm{b} 1}$

$2.05 \pm 0.06^{\mathrm{a} 1}$

120

$3.12 \pm 0.07^{\mathrm{b} 1}$

$3.07 \pm 0.04^{\mathrm{a} 1}$ 
Yeast and mold count (log CFU/g of sample)

0

30

60

90

120

150

180
ND

ND

ND

$2.01 \pm 0.03^{\mathrm{b} 1}$

$2.67 \pm 0.07^{\mathrm{b} 1}$

$3.03 \pm 0.22^{\mathrm{b} 1}$

$3.88 \pm 0.09^{\mathrm{b} 2}$
ND

ND

ND

$1.71 \pm 0.02^{\mathrm{a} 1}$

$1.96 \pm 0.07^{\mathrm{a} 1}$

$2.54 \pm 0.02^{\mathrm{a} 1}$

$2.91 \pm 0.07^{\mathrm{a} 2}$

$N D$ not detected, $C F U$ colony forming unit

Values are presented as mean \pm standard deviation $(n=3)$

Values with different alphabetical superscripts in a column differ significantly at $p<0.05$ for each test

Values with different numerical superscripts in a row differ significantly at $p<0.05$ for each test

Table 3 Check-all-that-apply (CATA) frequency table for quality attributes of UHT treated foxtail millet porridge stored at $25^{\circ} \mathrm{C}$ for different storage times

\begin{tabular}{|c|c|c|c|c|c|c|c|c|c|c|}
\hline \multirow[t]{2}{*}{ Attribute } & \multicolumn{10}{|c|}{ Storage time (days) } \\
\hline & $\mathbf{0}$ & 20 & 40 & 60 & 80 & 100 & 120 & 140 & 160 & 180 \\
\hline \multicolumn{11}{|c|}{ Visual texture and appearance: } \\
\hline Thick $^{*}$ & $10^{\mathrm{a}}$ & $10^{\mathrm{a}}$ & $10^{\mathrm{a}}$ & $12^{\mathrm{a}}$ & $12^{\mathrm{a}}$ & $12^{\mathrm{a}}$ & $12^{\mathrm{a}}$ & $13^{\mathrm{a}}$ & $13^{\mathrm{a}}$ & $13^{\mathrm{a}}$ \\
\hline Unevenness $^{+}$ & $12^{\mathrm{a}}$ & $12^{\mathrm{a}}$ & $12^{\mathrm{a}}$ & $11^{\mathrm{a}}$ & $11^{\mathrm{a}}$ & $11^{\mathrm{a}}$ & $10^{\mathrm{a}}$ & $10^{\mathrm{a}}$ & $9^{a}$ & $9^{a}$ \\
\hline $\begin{array}{l}\text { Uniform } \\
\text { color }^{*}\end{array}$ & $72^{\mathrm{a}}$ & $74^{\mathrm{ab}}$ & $75^{\mathrm{ab}}$ & $78^{\mathrm{b}}$ & $78^{\mathrm{b}}$ & $80^{\mathrm{abc}}$ & $83^{c}$ & $84^{\mathrm{c}}$ & $84^{\mathrm{c}}$ & $86^{\mathrm{c}}$ \\
\hline $\begin{array}{l}\text { Discoloratio } \\
\mathrm{n}^{+}\end{array}$ & $5^{\mathrm{a}}$ & $5^{\mathrm{a}}$ & $5^{\mathrm{a}}$ & $4^{\mathrm{a}}$ & $5^{\mathrm{a}}$ & $3^{\mathrm{b}}$ & $4^{\mathrm{a}}$ & $3^{\mathrm{b}}$ & $2^{\mathrm{b}}$ & $4^{\mathrm{a}}$ \\
\hline Curdling $^{+}$ & $2^{\mathrm{a}}$ & $2^{\mathrm{a}}$ & $2^{\mathrm{a}}$ & $3^{\mathrm{a}}$ & $4^{\mathrm{a}}$ & $4^{\mathrm{a}}$ & $4^{\mathrm{a}}$ & $8^{\mathrm{ab}}$ & $12^{\mathrm{b}}$ & $14^{\mathrm{b}}$ \\
\hline
\end{tabular}




\section{In mouth texture:}

$\begin{array}{lcccccccccc}\text { Grainy }^{*} & 71^{\mathrm{c}} & 69^{\mathrm{b}} & 69^{\mathrm{b}} & 68^{\mathrm{b}} & 68^{\mathrm{b}} & 64^{\mathrm{ab}} & 61^{\mathrm{a}} & 61^{\mathrm{a}} & 61^{\mathrm{a}} & 60^{\mathrm{a}} \\ \text { Sticky }^{+} & 42^{\mathrm{a}} & 43^{\mathrm{a}} & 43^{\mathrm{a}} & 45^{\mathrm{ab}} & 45^{\mathrm{ab}} & 49^{\mathrm{b}} & 50^{\mathrm{b}} & 51^{\mathrm{b}} & 54^{\mathrm{c}} & 56^{\mathrm{c}}\end{array}$

Smell:

Caramel $^{*} \quad 35^{\mathrm{a}} \quad 35^{\mathrm{a}} \quad 36^{\mathrm{a}} \quad 36^{\mathrm{a}} \quad 38^{\mathrm{a}} \quad 42^{\mathrm{ab}} \quad 44^{\mathrm{abc}} \quad 48^{\mathrm{bc}} \quad 51^{\mathrm{c}} \quad 52^{\mathrm{c}}$

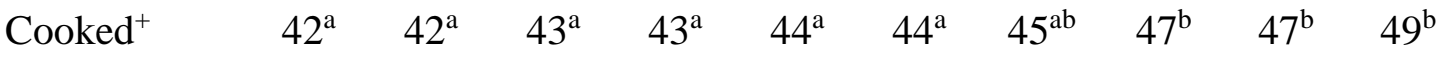

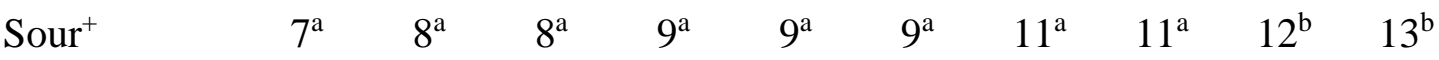

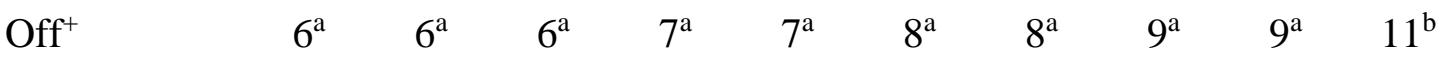

Taste:

Caramel $^{*} \quad 58^{\mathrm{a}} \quad 59^{\mathrm{a}} \quad 6^{\mathrm{ab}} \quad 68^{\mathrm{b}} \quad 69^{\mathrm{b}} \quad 74^{\mathrm{bc}} \quad 75^{\mathrm{bc}} \quad 79^{\mathrm{c}} \quad 82^{\mathrm{c}} \quad 83^{\mathrm{c}}$

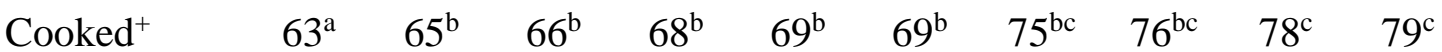

$\begin{array}{lllllllllll}\text { Sour }^{+} & 8^{\mathrm{a}} & 8^{\mathrm{a}} & 9^{\mathrm{a}} & 9^{\mathrm{a}} & 9^{\mathrm{a}} & 9^{\mathrm{a}} & 10^{\mathrm{a}} & 11^{\mathrm{a}} & 11^{\mathrm{a}} & 12^{\mathrm{a}}\end{array}$

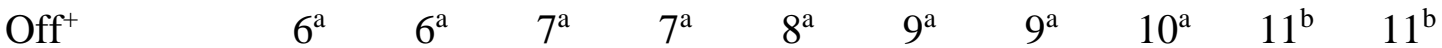

Values with different superscripts in rows represent significant differences $(\mathrm{p}<0.05, \mathrm{n}=100)$

"Positive sensory attributes

${ }^{+}$Negative sensory attributes

Table 4 Check-all-that-apply (CATA) frequency table for quality attributes of retort processed foxtail millet porridge stored at $25{ }^{\circ} \mathrm{C}$ for different storage times

\begin{tabular}{|c|c|c|c|c|c|c|c|c|c|c|}
\hline \multirow[t]{2}{*}{ Attribute } & \multicolumn{10}{|c|}{ Storage time (days) } \\
\hline & $\mathbf{0}$ & 20 & 40 & 60 & 80 & 100 & 120 & 140 & 160 & 180 \\
\hline \multicolumn{11}{|c|}{ Visual texture and appearance: } \\
\hline Thick $^{*}$ & $42^{\mathrm{a}}$ & $43^{\mathrm{a}}$ & $43^{\mathrm{a}}$ & $43^{\mathrm{a}}$ & $45^{\mathrm{a}}$ & $46^{\mathrm{ab}}$ & $48^{\mathrm{ab}}$ & $49^{b}$ & $49^{\mathrm{b}}$ & $52^{\mathrm{b}}$ \\
\hline Unevenness $^{+}$ & $21^{\mathrm{a}}$ & $23^{\mathrm{a}}$ & $23^{\mathrm{a}}$ & $26^{\mathrm{b}}$ & $27^{\mathrm{b}}$ & $28^{\mathrm{bc}}$ & $28^{\mathrm{bc}}$ & $32^{\mathrm{c}}$ & $33^{c}$ & $34^{\mathrm{c}}$ \\
\hline $\begin{array}{l}\text { Uniform } \\
\text { color }^{*}\end{array}$ & $78^{\mathrm{a}}$ & $79^{\mathrm{a}}$ & $79^{\mathrm{a}}$ & $80^{\mathrm{a}}$ & $84^{\mathrm{ab}}$ & $85^{\mathrm{b}}$ & $86^{\mathrm{b}}$ & $89^{\mathrm{bc}}$ & $94^{\mathrm{c}}$ & $95^{\mathrm{c}}$ \\
\hline $\begin{array}{l}\text { Discoloratio } \\
\mathrm{n}^{+}\end{array}$ & $11^{\mathrm{a}}$ & $12^{\mathrm{a}}$ & $12^{\mathrm{a}}$ & $13^{\mathrm{a}}$ & $14^{\mathrm{a}}$ & $15^{\mathrm{a}}$ & $16^{\mathrm{a}}$ & $16^{\mathrm{a}}$ & $17^{\mathrm{b}}$ & $19^{\mathrm{b}}$ \\
\hline
\end{tabular}




$\begin{array}{lllllllllll}\text { Curdling }^{+} & 4^{\mathrm{a}} & 5^{\mathrm{a}} & 5^{\mathrm{a}} & 5^{\mathrm{a}} & 6^{\mathrm{a}} & 6^{\mathrm{a}} & 7^{\mathrm{a}} & 8^{\mathrm{a}} & 8^{\mathrm{a}} & 9^{\mathrm{a}}\end{array}$

In mouth texture:

$\begin{array}{lllllllllll}\text { Grainy }^{*} & 83^{\mathrm{c}} & 82^{\mathrm{c}} & 78^{\mathrm{bc}} & 75^{\mathrm{b}} & 74^{\mathrm{b}} & 73^{\mathrm{b}} & 72^{\mathrm{b}} & 69^{\mathrm{a}} & 69^{\mathrm{a}} & 68^{\mathrm{a}} \\ \text { Sticky }^{+} & 54^{\mathrm{a}} & 56^{\mathrm{a}} & 58^{\mathrm{a}} & 62^{\mathrm{b}} & 63^{\mathrm{b}} & 65^{\mathrm{bc}} & 67^{\mathrm{c}} & 68^{\mathrm{c}} & 68^{\mathrm{c}} & 70^{\mathrm{c}}\end{array}$

Smell:

Caramel $^{*} \quad 68^{\mathrm{a}} \quad 68^{\mathrm{a}} \quad 69^{\mathrm{a}} \quad 7^{\mathrm{a}} \quad 7^{\mathrm{ab}} \quad 7^{\mathrm{b}} \quad 9^{\mathrm{b}} \quad 79^{\mathrm{b}} \quad 83^{\mathrm{bc}} \quad 84^{\mathrm{bc}} \quad 88^{\mathrm{c}}$

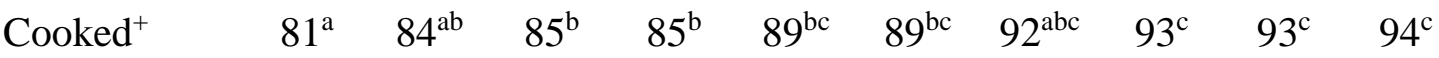

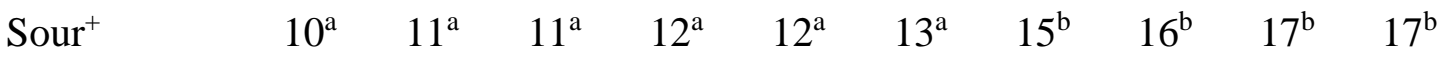

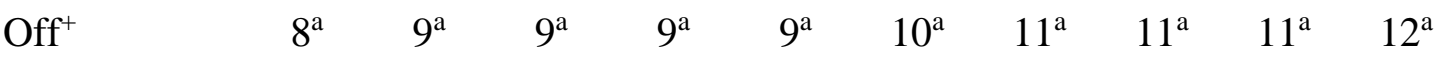

Taste:

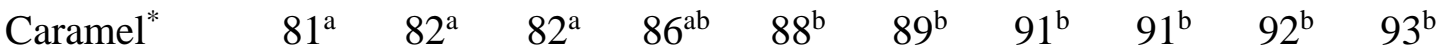

$\begin{array}{lllllllllll}\text { Cooked }^{+} & 80^{\mathrm{a}} & 80^{\mathrm{a}} & 81^{\mathrm{a}} & 82^{\mathrm{a}} & 83^{\mathrm{a}} & 83^{\mathrm{a}} & 85^{\mathrm{b}} & 87^{\mathrm{b}} & 87^{\mathrm{b}} & 88^{\mathrm{b}}\end{array}$

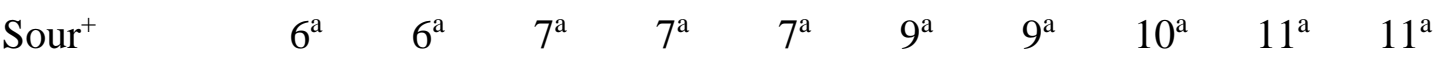

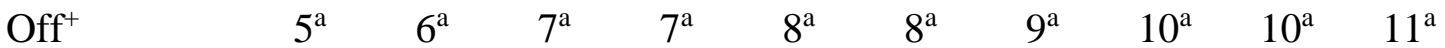

651

652

653

654

655

Table 5 Comparison of log-likelihood values for different distribution curves

Values with different superscripts in rows represent significant differences $(\mathrm{p}<0.05, \mathrm{n}=100)$

*Positive sensory attributes

${ }^{+}$Negative sensory attributes
Distribution model

Weibull

Logistic

Gaussian

Log-logistic

Exponential
Log-likelihood values

128.3

131.4

134.6

129.2

138.9 
660

661

662

663

664

665

666

667

668

669

670 

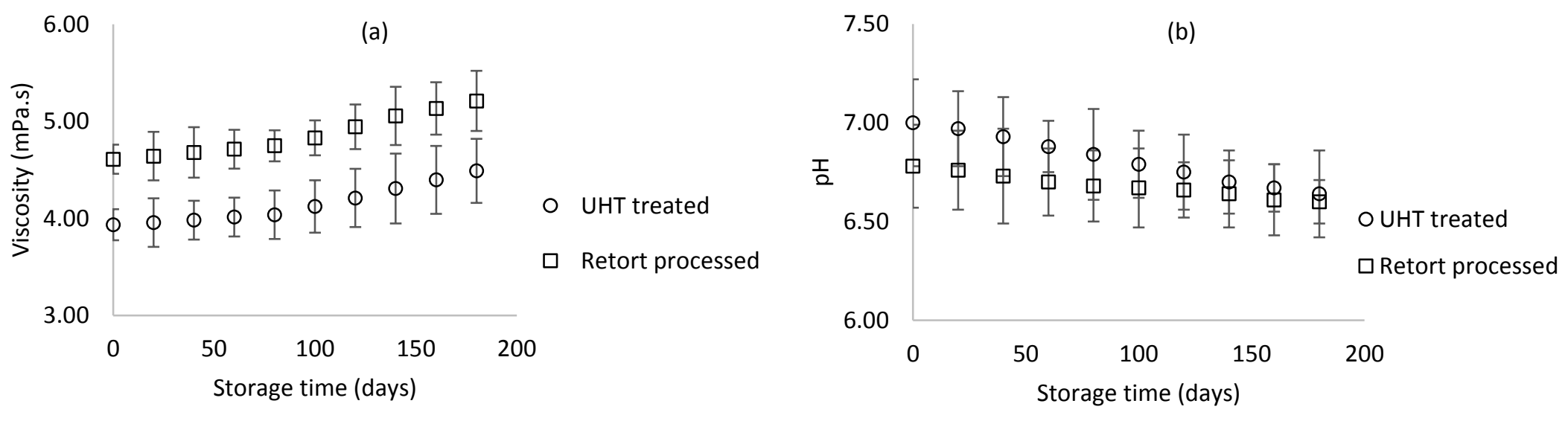

671

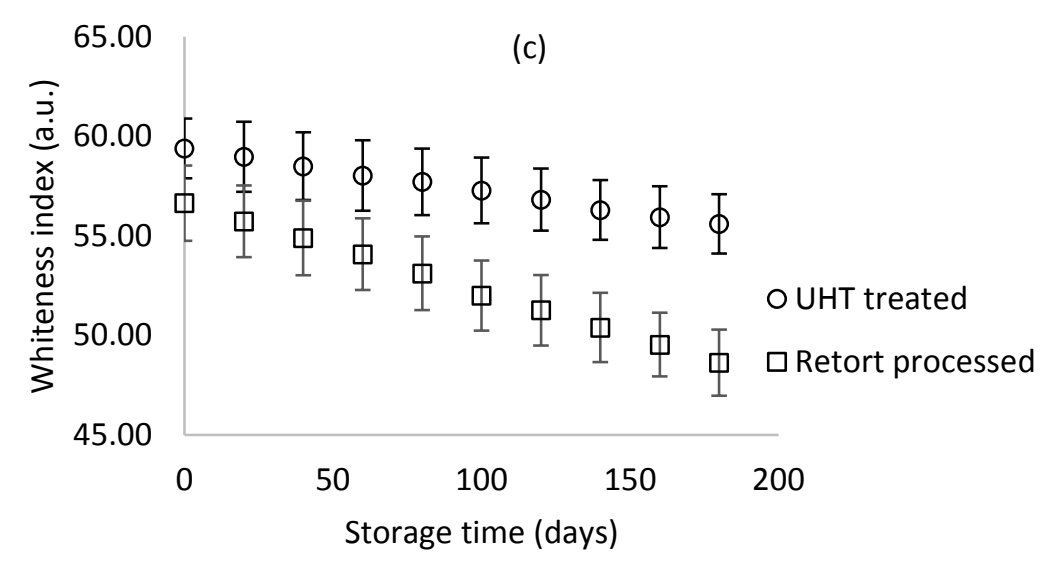

672

673 Figure 1 Changes in (a) viscosity, (b) $\mathrm{pH}$, and (c) whiteness index during storage of packaged foxtail millet porridge at $25{ }^{\circ} \mathrm{C}$. 
675
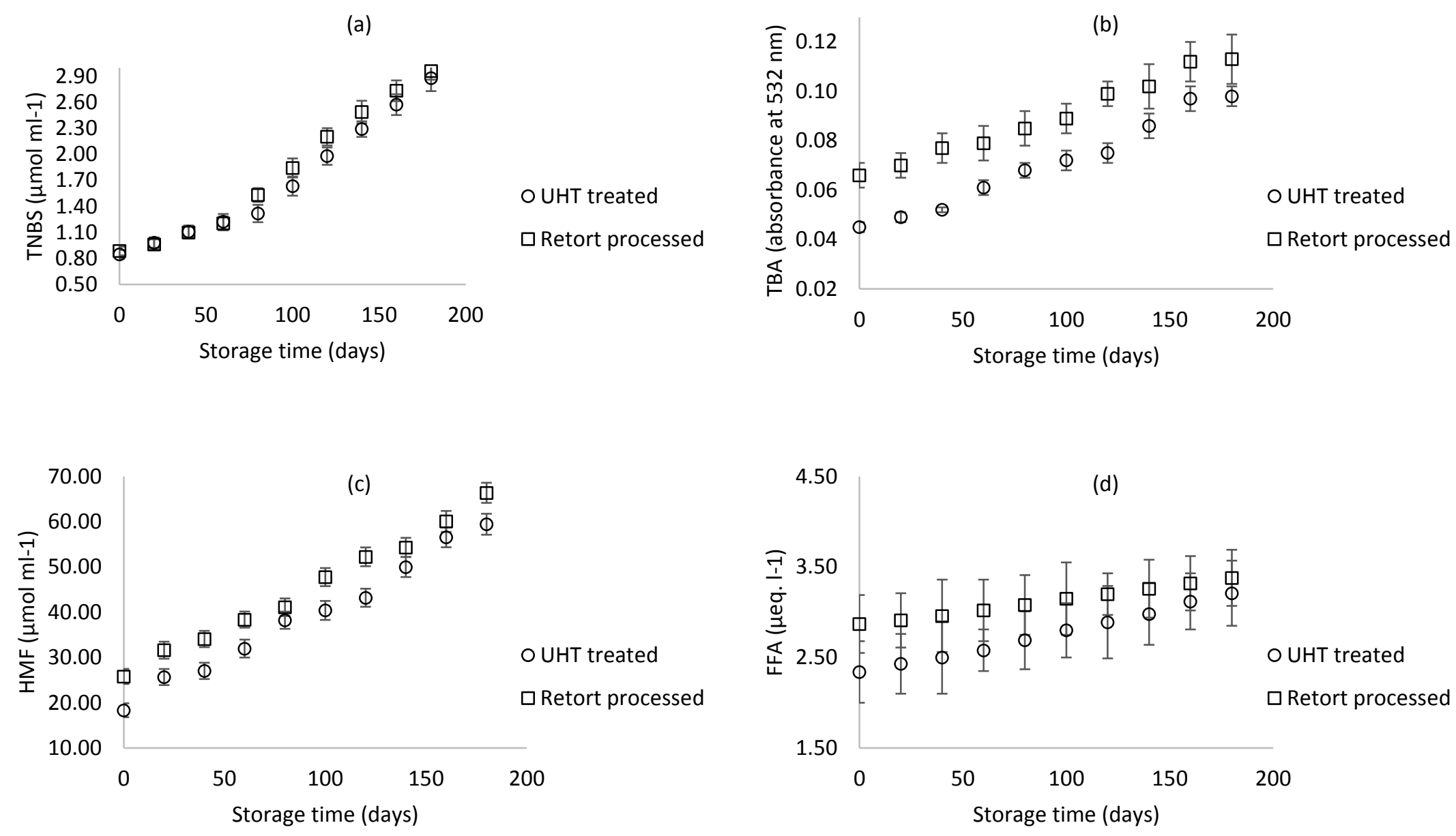

677 Figure 2 Changes in (a) trinitrobenzene sulfonic acid (TNBS), (b) thiobarbituric acid (TBA), (c) hydroxymethylfurfural (HMF), and (d) free fatty acid (FFA) value during storage of packaged foxtail millet porridge at $25{ }^{\circ} \mathrm{C}$. 

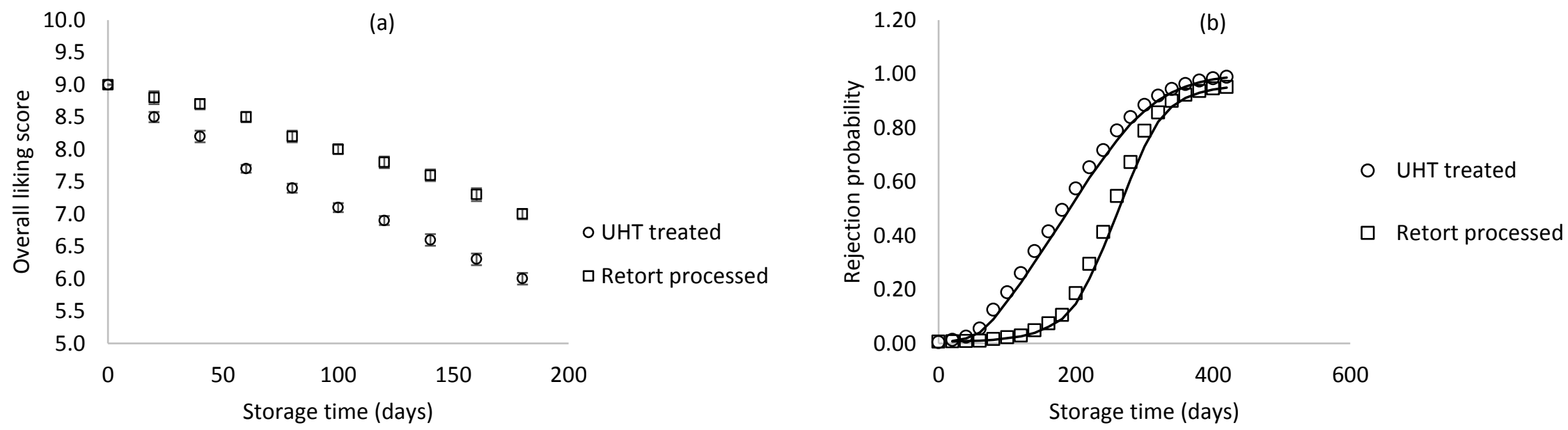

681 millet porridge stored at $25{ }^{\circ} \mathrm{C}$ 